$$
\begin{aligned}
& \text { CONF-970332--10 } \\
& \text { ANL/ET/CP - } 91605
\end{aligned}
$$

CORROSION PERFORMANCE OF CERAMIC MATERIALS IN SLAGGING ENVIRONMENTS*

\author{
K. Natesan \\ Energy Technology Division \\ Argonne National Laboratory \\ 9700 South Cass Avenue \\ Argonne, Illinois 60439
}

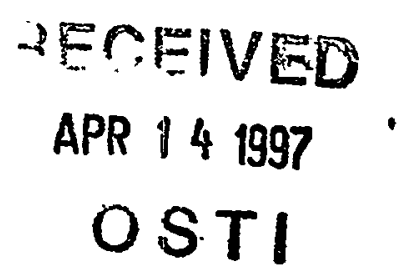

October 1996

\begin{abstract}
The submitted manuscript has been created by the University of Chicago as Operator of Argonne National Laboratory ("Argonne") under Contract No. W-31-109-ENG-38 with the U.S. Department of Energy. The U.S. Government retains for itself, and others acting on its behalf, a paid-up, nonexclusive, irrevocable worldwide license in said article to reproduce, prepare derivative works, distribute copies to the public, and perform publicly and display publichy, by or on behalf of the Government.
\end{abstract}
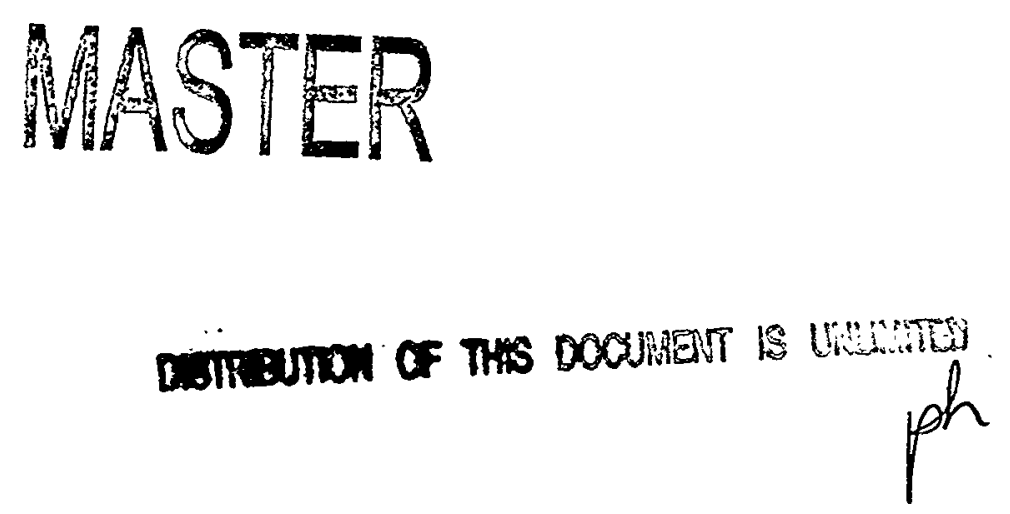

Invited paper for presentation at NACE CORROSION 97 Conference, New Orleans, LA, March 9-14, 1997.

*Work supported by the U.S. Department of Energy, Office of Fossil Energy, Advanced Research and Special Technologies Materials Program, under Contract W-31-109-Eng-38. 


\section{DISCLAIMER}

This report was prepared as an account of work sponsored by an agency of the United States Government. Neither the United States Government nor any agency thereof, nor any of their employees, make any warranty, express or implied, or assumes any legal liability or responsibility for the accuracy, completeness, or usefulness of any information, apparatus, product, or process disclosed, or represents that its use would not infringe privately owned rights. Reference herein to any specific commercial product, process, or service by trade name, trademark, manufacturer, or otherwise does not necessarily constitute or imply its endorsement, recommendation, or favoring by the United States Government or any agency thereof. The views and opinions of authors expressed herein do not necessarily state or reflect those of the United States Government or any agency thereof. 



\section{DISCLAIMIER}

Portions of this document may be illegible in electronic image products. Images are produced from the best available original document. 



\title{
CORROSION PERFORMANCE OF CERAMIC MATERIALS IN SLAGGING ENVIRONMENTS
}

\author{
K. Natesan \\ Energy Technology Division \\ Argonne National Laboratory \\ 9700 South Cass Avenue \\ Argonne, Illinois 60439
}

\begin{abstract}
Conceptual designs of advanced combustion systems that utilize coal as a feedstock require high-temperature furnaces and heat transfer surfaces that can operate at temperatures much higher than those prevalent in current coal-fired power plants. The combination of elevated temperatures and hostile combustion environments requires the development and application of advanced ceramic materials in these designs. The objectives of the present program are to evaluate the (a) chemistry of gaseous and condensed products that arise during combustion of coal; (b) corrosion behavior of candidate materials in air, slag, and salt environments for application in the combustion environments; and (c) residual mechanical properties of the materials after corrosion. The program emphasizes temperatures in the range of $1000-1400^{\circ} \mathrm{C}$ for ceramic materials and $600-1000^{\circ} \mathrm{C}$ for metallic alloys. Coal/ash chemistries developed on the basis of thermodynamic/kinetic calculations, together with slags from actual combustors, are used in the program. The materials being evaluated include monolithic silicon carbide from several sources: silicon nitride, silicon carbide in alumina composites, silicon carbide fibers in a silicon carbide-matrix composite, and some advanced nickelbase alloys. The paper presents results from an ongoing program on corrosion performance of candidate ceramic materials exposed to air, salt, and slag environments and their effect on flexural strength and energy absorbed during fracture of these materials.
\end{abstract}

Keywords: corrosion, ceramics, coal ash, silicon carbide, mechanical properties, thermodynamics

\section{INTRODUCTION}

Coal is a complex and relatively dirty fuel that contains varying amounts of sulfur and a substantial fraction of noncombustible mineral constituents, commonly called ash. Conceptual designs of high-performance power systems (HIPPS) that utilize coal as a feedstock require hightemperature furnaces and heat transfer surfaces capable of operating at higher temperatures than 
those used in conventional coal-fired power plants. The combination of elevated temperatures and hostile combustion environments requires the use of ceramic materials in at least the first few passes of the heat exchangers in these designs.

The HIPPS concept would employ a combined cycle that uses a gas turbine driven by a working fluid (air) that is separately heated in a high-temperature advanced furnace, in addition to conventional steam turbines. ${ }^{1}$ The targeted requirements for an HIPPS system are:

- A minimum conversion efficiency of $47 \%$.

- $\mathrm{NO}_{\mathrm{x}}<0.06 \mathrm{lb}$ (as $\mathrm{NO}_{2}$ ) per million Btu of fuel input.

- $\mathrm{SO}_{\mathrm{X}}<0.06 \mathrm{lb}\left(\right.$ as $\mathrm{SO}_{2}$ ) per million Btu of fuel input.

- Particulates $<0.003 \mathrm{lb}$ per million Btu of fuel input.

- Reduce $\mathrm{CO}_{2}$ emissions by 25 to $30 \%$.

- All solid waste streams must be benign.

- Initially, fuels will be coal and natural gas, with coal providing at least $65 \%$ of heat input and ultimately increasing to $95 \%$.

- The commercial plant will have a $65 \%$ annual capacity factor and generate electricity at a $10 \%$ lower (than present) cost.

The pulverized-coal high-temperature advanced furnace (HITAF) in the HIPPS concept will heat air to an intermediate temperature of $\approx 1000^{\circ} \mathrm{C}$ and burn supplemental clean fuel to boost the temperature of air to the turbine inlet temperature of $\geq 1300^{\circ} \mathrm{C}$. Use of supplemental fuel can be reduced as the HITAF technology evolves to permit air to be heated to higher temperatures in the furnace. HITAF represents a major departure from conventional pulverized-coal-fired boilers in which only steam is raised to a maximum of $530-620^{\circ} \mathrm{C}$. The purpose of the HITAF is to heat the clean working fluid - air - to the required turbine inlet temperatures. At the elevated temperatures of the HITAF, transfer of heat from the combustion gases to the working fluid will be dominated by radiative heat transfer, and the design of the heat transfer surface will be critical for success of the system. Several concepts are under development for the design of the heat transfer surfaces in the HITAF system. The concept proposed by the Foster Wheeler Development Corporation uses a pyrolysis process to convert the coal into low-Btu fuel gas and char. ${ }^{2}$ The cleaned fuel gas is burned in areas of the HITAF where ash deposition could be a problem. The concept proposed by the United Technologies Research Center uses a combustor with a controlled fuel distribution/long axial flame in which the heat release is stretched out, allowing for progressive heat removal. ${ }^{3}$ The compressed air is heated to $700^{\circ} \mathrm{C}$ in a convective air heater and then to $1000^{\circ} \mathrm{C}$ in a radiative air heater. A protective refractory layer on the fire side of the radiant air heater prevents corrosion of air passages by ash and slag, which inevitably will be deposited on the heat transfer surface. This concept also involves heating of the air with supplemental natural gas firing to achieve a $1300^{\circ} \mathrm{C}$ turbine inlet temperature.

Irrespective of which of these (or any other) concepts becomes viable for a commercial-scale HIPPS, it is evident that the heat transfer surfaces will be exposed to much higher temperatures than are prevalent in conventional coal-fired steam-turbine systems. For temperatures in the range of $1000-1300^{\circ} \mathrm{C}$, conventional metallic materials do not possess adequate strength properties and/or corrosion resistance for long-term service. In addition, an important difference between the conventional boiler system and the HIPPS is seen in the chemical and physical characteristics of the ash layers that can deposit on the heat transfer surfaces. The deposits are likely to be dominated by alkali sulfates and coal slags in HIPPS rather than by pyrosulfates or alkali-iron-trisulfates (which are prevalent in conventional pulverized coal-fired boilers) and by the increased mobility of corrosion-accelerating agents in the deposit layers due to the much higher temperature of the heat transfer surfaces in HIPPS. A major challenge is to develop methods to combat severe deposition, erosion, and corrosion (DEC) of heat transfer surfaces exposed to higher-than-normal temperatures. These methods could include fuel selection, cleaning of aggressive contaminants from coal, fine grinding of coal, use of additives, and selection of advanced corrosion-resistant ceramic materials, coatings, and advanced alloys for vulnerable heat transfer sections. 
The objectives of the present program are to evaluate the (a) chemistry of gaseous and condensed products that arise in combustion of coal and (b) candidate materials for application in the combustion environments. Chemistry calculations determine the types and amounts of combustion products over the wide temperature range of $700-1700^{\circ} \mathrm{C}$ and at 1 atm pressure. The experimental program on heat exchanger materials will develop mechanistic information on the roles of material composition, ash constituents, combustion deposits, chlorine, alkali sulfates, and sulfur sorbents in the corrosion process. The program emphasizes corrosion evaluation of materials in air, salt, and coal/ash environments at temperatures between 1000 and $1400^{\circ} \mathrm{C}$, as well as measurement of residual fracture properties of the materials after corrosion. Coal/ash chemistries synthesized on the basis of thermodynamic/kinetic calculations, together with slags from actual combustors, are used in the program. The paper presents selected results on several materials exposed in both laboratory tests and in the Combustion and Environmental Research Facility (CERF) at DOE's Pittsburgh Energy Technology Center.

Thermodynamic calculations were used to evaluate the chemistries of gaseous and condensed phases that occur during combustion of an Illinois bituminous coal. The computer program used for the calculations is based on calculating the equilibrium concentrations of various species by minimizing the free energy of the system. Details of the calculations are presented in Ref. 4. Calculated results for the chemistry of condensed phases and the gaseous phase at the combustion air:coal stoichiometric ratio of 1.3 showed that coal combustion results in a liquid phase that is essentially a silica-saturated silicate and/or sulfate condensate, with the components made up largely of $\mathrm{SiO}_{2}$, $\mathrm{Al}_{2} \mathrm{O}_{3}, \mathrm{CaO}, \mathrm{Fe}_{2} \mathrm{O}_{3}, \mathrm{Na}_{2} \mathrm{SO}_{4}$, and $\mathrm{NaCl}$ (see Fig. 2). At temperatures below $1180^{\circ} \mathrm{C}$, the partial pressures of $\mathrm{NaCl}(\mathrm{g}), \mathrm{HCl}(\mathrm{g}), \mathrm{NaOH}(\mathrm{g})$, and $\mathrm{Na}(\mathrm{g})$ change abruptly; a complex sodium aluminosilicate, $\mathrm{Na}_{2} \mathrm{O} \cdot \mathrm{Al}_{2} \mathrm{O}_{3} \cdot 6 \mathrm{SiO}_{2}(\mathrm{~s})$, tends to form; and the liquid silicate-sulfate condensate disappears. Formation of the complex silicate requires intimate contact among several gaseous and condensed phases, but the probability of such contact is expected to be low in real systems. Under nonequilibrium conditions, where such reactions are constrained, stability of the liquid sulfate-silicate condensate extends to temperatures as low as $890^{\circ} \mathrm{C}$.

Above $1330^{\circ} \mathrm{C}$, the solution consists mostly of $\mathrm{Al}_{2} \mathrm{O}_{3} \cdot \mathrm{SiO}_{2}, \mathrm{CaO} \cdot \mathrm{SiO}_{2}, \mathrm{Na} 2 \mathrm{O} \cdot \mathrm{SiO}_{2}$, and $\mathrm{FeO} \cdot \mathrm{SiO}_{2}$, as well as traces of $\mathrm{Na}_{2} \mathrm{SO}_{4}$. As the temperature decreases, the concentration of $\mathrm{FeO} \cdot \mathrm{SiO} 2$ decreases and that of $\mathrm{Na}_{2} \mathrm{SO}_{4}$ increases. At $1130^{\circ} \mathrm{C}, \mathrm{Na}_{2} \mathrm{SO}_{4}$ concentration may be relatively high (about $12 \mathrm{~mol} \%$ for high-sulfur coal) and may increase very rapidly with a decrease in temperature. Under nonequilibrium conditions, the solution phase is rich in $\mathrm{Na}_{2} \mathrm{SO}_{4}$. For high-sulfur coal at temperatures below $930^{\circ} \mathrm{C}$, the solution phase consists of more than 90 mol\% sulfate. A solution phase consisting of sodium, magnesium, and calcium sulfates is stable below $880^{\circ} \mathrm{C}$. The transition from silicate sulfate to sulfates occurs within the temperature range of $1130-980^{\circ} \mathrm{C}$.

Based on the results of these calculations, the general behavior of the solution phase under oxidizing conditions can be described as follows. A liquid solution phase, consisting mostly of silicates of aluminum, calcium, sodium, magnesium, and iron, is present at $1730^{\circ} \mathrm{C}$. The mole fraction of $\mathrm{Na}_{2} \mathrm{SO}_{4}$ phase in the liquid is $<0.01$ above $1280^{\circ} \mathrm{C}$. The concentration of $\mathrm{Na}_{2} \mathrm{SO}_{4}$ rises rapidly as the temperature decreases and becomes a major component of the solution at $980^{\circ} \mathrm{C}$. The mole fraction of $\mathrm{Na}_{2} \mathrm{SO}_{4}$ may increase to 0.9 or more at $980^{\circ} \mathrm{C}$. These compositional changes can have implications for the corrosive behavior of the liquid condensates. In the temperature range of interest in HIPPS, the predominant deposits are either mullite or Ca-rich aluminosilicates. The silicate liquid may be even more corrosive and have worse fouling tendencies than sulfates because of (a) high temperature conditions, (b) adhesive behavior of the silicates, and (c) solubility of ceramic materials, which are probably higher in silicate than in sulfate melts.

\section{EXPERIMENTAL PROCEDURE}

\section{Laboratory Experiments}

The materials selected for the laboratory experimental program include advanced metallic alloys, monolithic ceramic materials, and ceramic-matrix ceramic composites; they are listed in Table 1, together with their manufacturers. Hexoloy SA is a sintered form of alpha silicon carbide with $>98 \%$ of theoretical density. It has a very fine grain structure $(8 \mu \mathrm{m})$ for excellent wear resistance, contains no free silicon, and has been reported to be chemically resistant in both oxidizing and reducing environments. $\mathrm{SiC}(\mathrm{p})$ in $\mathrm{Al}_{2} \mathrm{O}_{3}$ material was fabricated by DuPont-Lanxide by a direct metal 
oxidation process and has an $\mathrm{Al}_{2} \mathrm{O}_{3}$ matrix with $\mathrm{SiC}$ particulates dispersed throughout the matrix. The material also exhibited some free $\mathrm{Al}$ in the matrix. Siliconized SiC material (identified as NT 230) is made by Norton/TRW. $\mathrm{SiC}(\mathrm{f}) / \mathrm{SiC}$ matrix material is made by DuPont by a chemical vapor infiltration process. It is recommended for service requiring high strength, high-temperature properties, and light weight. The material exhibits creep deformation at temperatures $>1200^{\circ} \mathrm{C}$, contrary to behavior of Hexoloy SA and NT 230, in which creep is virtually absent. The SiC in Si matrix material is made by INEX. Inc., and has been used as tubes in natural-gas-fired heat exchangers. The material $\mathrm{SiC}$ fibers in Si nitride was fabricated by Oak Ridge National Laboratory.

Coupon specimens measuring $2 \mathrm{~cm} \times 2 \mathrm{~cm} \times 2-3 \mathrm{~mm}$ were prepared from several of the abovelisted materials for salt- and slag-exposure experiments. Dimensions and initial weights of the specimens were measured prior to exposure. Salt tests were conducted at 1000 and $1200^{\circ} \mathrm{C}$ in the presence of $\mathrm{Na}_{2} \mathrm{SO}_{4}$ or a mixture of $\mathrm{Na}_{2} \mathrm{SO}_{4}$ and $\mathrm{NaCl}$ for $168 \mathrm{~h}$. Tests in the presence of three different slags were conducted at $1200^{\circ} \mathrm{C}$ for a test time of $200 \mathrm{~h}$. Table 2 lists the compositions of slags and the coals that were combusted to obtain these slags. Analysis shows that the slag obtained from Illinois \#6 coal was richer in $\mathrm{Fe}_{2} \mathrm{O}_{3}$ and leaner in $\mathrm{CaO}$ and $\mathrm{MgO}$, while the reverse was seen for slag from the Rochelle coal. Slags \#43 and XX typify the slags derived from coals in the eastern U.S., while the \#47 is typical of that from western coals.

In addition, the effects of air oxidation, salt exposure, and exposures to slag from Illinois \#6 and Rochelle coals on the flexural strength of four of the candidate materials were evaluated by preexposure to the specific environment and by postexposure four-point bend testing of the specimens in vacuum. For these specimens, the temperature was maintained at $1200^{\circ} \mathrm{C}$ for both the preexposure and mechanical test. The flexural test involved bending a specimen of rectangular cross section until fracture. The specimen dimensions were $25.4 \times 4.76 \times 1.6 \mathrm{~mm}$ and the salt/slag exposed surface was maintained under tension during the test. The data on the load to cause fracture and the area under the load-displacement curves were used to calculate the flexural strength of the material and the energy absorbed during the fracture.

\section{Combustor Experiments}

High-temperature materials were tested by exposing samples of several ceramic materials in the Combustion and Environmental Research Facility (CERF) at the Pittsburgh Energy Technology Center. The CERF is a state-of-the-art, 0.5-million-Btu/h pilot-scale combustion facility designed to achieve similarity with full-scale utility and industrial boilers. The CERF is designed to closely duplicate typical full-scale specifications for:

- Solid fuel fineness or liquid fuel atomization quality.

- Burner relative mass flow (fuel and air) and velocities.

- Furnace temperature distributions.

- Radiant furnace residence time.

- Convective-section gas velocity.

Materials exposures in CERF are being conducted in a piggyback mode, whereby normal CERF testing proceeds in terms of evaluating combustion of various coals and coal blends. With this approach, comparative assessments of many materials at different locations could be made economically before pursuing dedicated-materials CERF tests that would require continuous operation of the facility for $1000 \mathrm{~h}$ or more. To minimize thermal stresses during exposure, samples were placed in the CERF prior to the start of each test and removed after the CERF was cooled to room temperature. Coupon samples of several of the ceramic materials (see list in Table 1) were mounted on a watercooled, high-temperature materials testing probe that uses welded clips and pins to hold the samples. Ceramic specimens were exposed during two 100-h runs in which Pittsburgh coal and a blend of Alaskan/Russian coal were burned. Table 3 shows compositions of coals used in CERF runs, along with coals that generated slags for the laboratory test program. 
Oxidation of ceramic materials such as monolithic and composite $\mathrm{SiC}, \mathrm{Si}_{3} \mathrm{~N}_{4}$, and $\mathrm{SiC}$ dispersed $\mathrm{Al}_{2} \mathrm{O}_{3}$ involves reaction of carbide and nitride phases to Si-rich oxides. The rate of oxidation is generally influenced by the porosity of the material and the exposure temperature. Figure 3 shows weight change data for several of the materials exposed to dry air at $1200^{\circ} \mathrm{C}$; it is evident that most of the $\mathrm{SiC}$ and $\mathrm{Si}_{3} \mathrm{~N}_{4}$ materials oxidize at a low rate at $1200^{\circ} \mathrm{C}$. The two exceptions are $\mathrm{SiC}(\mathrm{p})$ in $\mathrm{Al}_{2} \mathrm{O}_{3}$ and $\mathrm{SiC}(\mathrm{f}) / \mathrm{SiC}$ (ORNL). In the former, the increase in weight gain in the early stage of exposure is due to oxidation of free $\mathrm{Al}$ in the surface region of the sample. After $\approx 100 \mathrm{~h}$ exposure, the oxidation rate slows but is still higher than other materials indicating oxidation of free $\mathrm{Al}$ in the interior of the material dictated by the diffusion of oxygen. The increased rate of oxidation for the latter material can only be attributed to the porosity of the material because the oxidation rates are low for dense monolithic $\mathrm{SiC}$ materials. Oxidation of $\mathrm{SiC}$ can occur via either a passive mode in which a solid $\mathrm{SiO}_{2}$ phase forms and offers protection against further oxidation, or an active mode in which SiO phase forms and volatilizes, resulting in accelerated oxidation of the material. Figure 4 shows the regions of active and passive oxidation as functions of temperature and $\mathrm{pO}_{2} \cdot{ }^{6}$ Experiments conducted with these materials at temperatures in the range $1000-1400^{\circ} \mathrm{C}$ in dry air environment showed that the materials undergo passive oxidation.

\section{Exposure to Salt Environment}

Salt-induced degradation of these materials involves reactions between the ceramic materials and alkali sulfates such as $\mathrm{Na}_{2} \mathrm{SO}_{4}$ and $\mathrm{K}_{2} \mathrm{SO}_{4}$ and alkali chlorides such as $\mathrm{NaCl}$ and $\mathrm{KCl}$. In the combustion gas environment, the concentrations of oxygen and of sulfur as $\mathrm{SO}_{2}$ and $\mathrm{SO}_{3}$ determine the sodium oxide activity via the reaction $\mathrm{Na}_{2} \mathrm{SO}_{4}=\mathrm{Na}_{2} \mathrm{O}+\mathrm{SO}_{3}$. Subsequently, the silica phase that forms on the ceramic materials can react with $\mathrm{Na}_{2} \mathrm{O}$ to form compounds such as $\mathrm{Na}_{2} \mathrm{O} \cdot \mathrm{XSiO}_{2}$, where $\mathrm{X}$ can be $0.5,1,2$, or 4 . This mode of degradation of ceramic materials requires that $\mathrm{Na}_{2} \mathrm{O}$ activity be sufficiently high and is usually possible in gas turbine systems where slag constituents are virtually absent. In such instances, the liquid phase can dissolve the protective $\mathrm{SiO}_{2}$ scale and also result in penetration of the liquid reaction products into the substrate ceramic material, thereby mechanically weakening the material. To examine the effect of salt deposit, specimens were exposed for $168 \mathrm{~h}$ at $1200^{\circ} \mathrm{C}$ to a gas stream of composition 1 vol.\% $\mathrm{SO}_{2}$-Air which was passed over $\mathrm{Na}_{2} \mathrm{SO}_{4}$ salt maintained at temperatures between 700 and $1400^{\circ} \mathrm{C}$. The materials selected for these tests were Hexoloy SA, $\mathrm{SiC}(\mathrm{p}) / \mathrm{Al}_{2} \mathrm{O}_{3}$, NT 230 , and NT 154. Figure 5 shows specimen weight change at $1200^{\circ} \mathrm{C}$ after $168 \mathrm{~h}$ exposure to salt at different temperatures. $\mathrm{Na}_{2} \mathrm{SO}_{4}$ has a melting temperature of $884^{\circ} \mathrm{C}$ and samples exposed to salt at temperatures of $700-900^{\circ} \mathrm{C}$ did not exhibit significant corrosion. The weight increase of the $\mathrm{SiC}(\mathrm{p}) / \mathrm{Al}_{2} \mathrm{O}_{3}$ is primarily due to oxidation of free $\mathrm{Al}$ in the material. Even at a salt temperature of $1000^{\circ} \mathrm{C}$, the vapor pressure of $\mathrm{Na}_{2} \mathrm{SO}_{4}$ is low enough not to cause any significant corrosion of the exposed materials. At a salt temperature of $1200^{\circ} \mathrm{C}$ and higher, corrosion of the SiC-based materials was evident while the $\mathrm{SiC}(\mathrm{p}) / \mathrm{Al}_{2} \mathrm{O}_{3}$ was resistant to salt-induced corrosion. In the absence of $\mathrm{Al}_{2} \mathrm{O}_{3}$, the monolithic and composite $\mathrm{SiC}$ and $\mathrm{Si}_{3} \mathrm{~N}_{4}$ materials oxidize to form $\mathrm{SiO}_{2}$, which reacts with $\mathrm{Na}_{2} \mathrm{SO}_{4}$ to form compounds of compositions $\mathrm{Na}_{2} \mathrm{O} \cdot \mathrm{XSiO}_{2}$ with melting temperatures of $875-1110^{\circ} \mathrm{C}$ and leads to enhanced corrosion. The presence of $\mathrm{Al}_{2} \mathrm{O}_{3}$ in the Lanxide/DuPont material leads to formation of mullite ( $\left.\mathrm{Na}_{2} \mathrm{O} . \mathrm{Al}_{2} \mathrm{O}_{3} .2 \mathrm{SiO}_{2}\right)$ with a melting temperature of $1526^{\circ} \mathrm{C}$, resulting in low corrosion, if any, at temperatures of 1200 and $1400^{\circ} \mathrm{C}$ in the present investigation. In coal-fired combustion systems, the presence of slag constituents determine the thermodynamic activity of various deposit constituents, and alkali-sulfate-induced corrosion is generally not dominant.

\section{Corrosion in Slag Environments}

In laboratory slag tests, the materials behaved differently than in salt tests. Specimens showed significant surface cracking but the slag itself did not seem to penetrate the specimens, as evidenced by energy-dispersive $\mathrm{X}$-ray (EDX) analysis of specimen cross sections. Because $\mathrm{Na}_{2} \mathrm{O}$ activity in the slag is relatively low, the deposit did not melt, but significant bubbling of the slag was noted, probably due to formation of $\mathrm{SiO}$ vapor in a reducing condition established locally by entrapped carbon in the slag. All 
three slags exhibited a similar appearance after the test and also all three specimens exposed to different slags appeared similar, indicating that coal slag chemistry has little influence in these short exposures. In the CERF exposure conducted with Pittsburgh coal, the specimen exhibited a thin layer of deposit after $\approx 100 \mathrm{~h}$ of testing. X-ray diffraction analysis of the deposit indicated predominantly mullite $\left(3 \mathrm{Al}_{2} \mathrm{O}_{3} \cdot 2 \mathrm{SiO}_{2}\right)$ with some ordered albite $\left[(\mathrm{Na}, \mathrm{Ca}) \mathrm{Al}(\mathrm{Si}, \mathrm{Al})_{3} \mathrm{O}_{8}\right]$ and traces of hematite. No significant degradation of the sample was observed in scanning electron microscopy (SEM) and EDX analysis. Figure 7 shows the composition envelope for the deposits observed on the specimens exposed during combustion of Illinois coal. In the CERF exposure conducted with Alaskan/Russian coal, the dominant phases were anorthite $\left(\mathrm{CaO} \cdot \mathrm{Al}_{2} \mathrm{O}_{3} \cdot 2 \mathrm{SiO}_{2}\right)$, calcium aluminum silicate $\left(\mathrm{CaO} \cdot \mathrm{Al}_{2} \mathrm{O}_{3} \cdot \mathrm{SiO}_{2}\right)$, and ordered sodium anorthite $(\mathrm{Ca}, \mathrm{Na})(\mathrm{Al}, \mathrm{Si})_{2} \mathrm{Si}_{2} \mathrm{O}_{8}$. These $\mathrm{Ca}$-rich silicates also have melting temperatures $>1400^{\circ} \mathrm{C}$, and reactions between the coal ash deposit and the ceramics occur predominantly in the solid state. Figure 8 shows the composition envelope for the deposits observed on the specimens exposed during combustion of Alaskan/Russian coal. The experimental results also indicate that $\mathrm{Na}_{2} \mathrm{O}$ activities in the deposits (with combustion of coals containing $\mathrm{Fe}_{2} \mathrm{O}_{3}$ and $\mathrm{CaO}$ ) are sufficiently low to form liquid sodium silicates of various types in coal-fired systems. This may indicate qualitatively that the material may be susceptible to cracking by particle impingement at elevated temperatures.

\section{Baseline Mechanical Properties}

Four-point bend tests were conducted on Hexoloy SA, NT 230, SiC in Si matrix, and SiC(f) in SiC matrix materials at 1000,1200 , and $1400^{\circ} \mathrm{C}$. The load to cause fracture measured in the test is used to calculate the flexural strength for the materials using the expression

$$
\sigma=\frac{3\left(L_{1}-L_{2}\right) P}{2 t^{2} w}
$$

where $\sigma$ is flexural strength in $\mathrm{MPa}, \mathrm{L}_{1}$ and $\mathrm{L}_{2}$ are distance between support points and load points, respectively, $P$ is load, $t$ and $w$ are thickness and width of the specimen, respectively. The testing technique produces a nonuniform stress distribution with the maximum tensile stress in the outer skin of the specimen. Figure 8 shows the flexural strength of the materials as a function of temperature. The results show that Hexoloy SA maintains fairly high strength in the range of 350-400 $\mathrm{MPa}$ at temperatures up to $1400^{\circ} \mathrm{C}$. Flexural strength for NT 230 is somewhat higher than that of Hexoloy SA upto $1200^{\circ} \mathrm{C}$ and seems to drop to $\approx 300 \mathrm{MPa}$ at $1400^{\circ} \mathrm{C}$ and to $\approx 180 \mathrm{MPa}$ at $1450^{\circ} \mathrm{C}$. The material $\mathrm{SiC}$ in $\mathrm{Si}$ matrix had relatively lower strength of $100-120 \mathrm{MPa}$ up to $1200^{\circ} \mathrm{C}$ and dropped to $\approx 70 \mathrm{MPa}$ at $1300^{\circ} \mathrm{C}$. The material $\mathrm{SiC}(\mathrm{f})$ in $\mathrm{SiC}$ matrix exhibited strength values comparable to Hexoloy $\mathrm{SA}$ at temperatures up to $1200^{\circ} \mathrm{C}$ but were lower at temperatures above $1200^{\circ} \mathrm{C}$ and were comparable to those observed for NT 230 material. Load-displacement curves from these baseline tests were also used to calculate the area under the curves, which is indicative of the energy absorbed during fracture. The absorbed energy values can differentiate between the monolithic and composite materials because the monolithic materials (such as Hexoloy SA) rarely exhibit little creep prior to fracture while the composites [such as, $\mathrm{SiC}(\mathrm{f}) / \mathrm{SiC}$ ] generally exhibit significant creep deformation prior to fracture. The fracture energy values for the materials are presented in the next section, along with the data obtained for the materials after exposure to corrosive environments.

\section{Effect of Corrosion on Mechanical Properties}

To examine the role of exposure environment on mechanical properties, several specimens of Hexoloy SA, NT 230, SiC in Si matrix, and SiC(f) in SiC matrix were preexposed for $200 \mathrm{~h}$ at $1200^{\circ} \mathrm{C}$ to dry air, $\mathrm{Na}_{2} \mathrm{SO}_{4}$ salt, $75 \mathrm{wt} . \% \mathrm{Na}_{2} \mathrm{SO}_{4}-25 \mathrm{wt} . \% \mathrm{NaCl}$ mixture, and three different coal slags identified as 43,47 , and XX. After exposure, the specimens were mechanically tested in vacuum at $1200^{\circ} \mathrm{C}$. In these tests, the specimen surfaces exposed to the salt and slag environments were on the support side of the fixture, ensuring a tensile mode of loading for the surfaces exposed to corrosive environments.

Figure 9 shows flexural strength of the four materials in as-received condition and after exposure to different environments. It is evident that exposures of $200 \mathrm{~h}$ in different environments had very influence on the strength of Hexoloy SA material. Analysis of fracture surfaces of exposed specimens showed formation of thin layers of silica in air exposure, and virtually no penetration of salt or slag was observed in other exposures. The density of this material being high, influence of corrosive attack on this material may require longer exposure times and/or higher temperatures. The 
NT 230 material exhibited fairly good strength after air exposure but had a significant loss in strength after exposure to salt that contained $\mathrm{NaCl}$. On the other hand, the presence of slags at $1200^{\circ} \mathrm{C}$ had very little effect on the strength of the material. The material SiC in Si matrix was fairly porous and the sample became fully corroded in the presence of the salt containing $\mathrm{NaCl}$ but did not exhibit significant loss in strength in the presence of other deposits. The composite material SiC(f) in SiC matrix also exhibited accelerated corrosion in the presence of salt containing $\mathrm{NaCl}$ but was affected minimally in other environments.

Figure 10 shows the absorbed energy per unit area for the four materials after $200 \mathrm{~h}$ exposure to different environments at $1200^{\circ} \mathrm{C}$. The absorbed energy values are in the range of $0.15-0.20 \mathrm{~J} / \mathrm{cm}^{2}$ for Hexoloy SA after exposure in air and slag environments. The low value, which is an average of three tests conducted at $1200^{\circ} \mathrm{C}$, for the as-received material cannot be explained at present. The lower values for the salt-exposed specimens may indicate some intergranular prenetration of salt, which was not obvious from SEM analysis of cross sections of the specimens. Absorbed energy values for the asreceived, air-exposed, and slag-exposed specimens of NT 230 were comparable, indicating that these environments are benign from the corrosion standpoint after $200 \mathrm{~h}$ of exposure at $1200^{\circ} \mathrm{C}$. The saltexposed specimens showed lower absorbed energy values similar to those for Hexoloy SA. Specimens of $\mathrm{SiC}$ in $\mathrm{Si}$ matrix had an inherently low value for energy-to-fracture and were not significantly affected by exposure in air and slag environments. The presence of sulfate salt seems to lower the fracture energy. The composite material $\mathrm{SiC}(\mathrm{f})$ in $\mathrm{SiC}$ matrix had the highest value (in the range of $0.25-0.40 \mathrm{~J} / \mathrm{cm}^{2}$ ) for the fracture energy among the four materials tested. The results also indicate that the salt environments have degrading effects on the strength properties of these materials but the presence of slag (simulating either eastern or western U.S. coals) had only minimal effect at $1200^{\circ} \mathrm{C}$ in $200 \mathrm{~h}$ exposures.

\section{DISCUSSION}

Corrosion of ceramic heat exchanger surfaces in coal-fired systems can occur via three different mechanisms dictated by the material composition and exposure environment (which includes temperature, gas chemistry, and deposit chemistry). The gas and deposit chemistries, in turn, will be dictated by the coal and ash chemistry, combustion conditions, and gas and particulate flow conditions determined by furnace design. The first mode of degradation of ceramic materials such as monolithic and composite $\mathrm{SiC}, \mathrm{Si}_{3} \mathrm{~N}_{4}$, and $\mathrm{SiC}$-dispersed $\mathrm{Al}_{2} \mathrm{O}_{3}$ is by oxidation of $\mathrm{SiC}$ and $\mathrm{Si}_{3} \mathrm{~N}_{4}$ in air. Oxidation can occur via either the passive mode in which a solid $\mathrm{SiO}_{2}$ phase forms and can offer protection against further oxidation, or active oxidation in which the SiO phase forms and can volatilize, resulting in accelerated oxidation of the material. The air-oxidation experiments conducted with these materials at temperatures in the range $1000-1400^{\circ} \mathrm{C}$ in dry air showed that the materials undergo passive oxidation. However, the effect of water vapor on oxidation needs further evaluation.

The second mode of degradation of these materials involves reactions between the ceramic materials and alkali sulfates such as $\mathrm{Na}_{2} \mathrm{SO}_{4}$ and $\mathrm{K}_{2} \mathrm{SO}_{4}$ and alkali chlorides such as $\mathrm{NaCl}$ and $\mathrm{KCl}$. In the combustion gas environment, the concentrations of oxygen and of sulfur as $\mathrm{SO}_{2}$ and $\mathrm{SO}_{3}$ determine the sodium oxide activity via the reaction $\mathrm{Na}_{2} \mathrm{SO}_{4}=\mathrm{Na}_{2} \mathrm{O}+\mathrm{SO}_{3}$. Subsequently, the silica phase that forms on the ceramic materials can react with $\mathrm{Na}_{2} \mathrm{O}$ to form compounds such as $\mathrm{Na}_{2} \mathrm{O} \cdot \mathrm{XSiO}_{2}$, where $\mathrm{X}$ can be $0.5,1,2$, or 4 . These sodium silicates have melting temperatures of $875-1110^{\circ} \mathrm{C}$. This mode of degradation of ceramic materials requires that $\mathrm{Na}_{2} \mathrm{O}$ activity be sufficiently high and is usually possible in gas turbine systems where slag constituents are virtually absent. In such instances, the liquid phase can dissolve the protective $\mathrm{SiO}_{2}$ scale and also result in penetration of the liquid reaction products into the substrate ceramic material, thereby mechanically weakening the material. In coalfired combustion systems, the presence of slag constituents determines the thermodynamic activity of various deposit constituents, and alkali-sulfate-induced corrosion is generally not dominant.

The third mode of degradation of ceramic materials in coal-fired combustion systems is via reactions with coal ash. This type of degradation depends on material composition, slag chemistry (acidic or basic), and gas-phase environment (either oxidizing or reducing). The slag generally contain phases such as $\mathrm{SiO}_{2}, \mathrm{Al}_{2} \mathrm{O}_{3}, \mathrm{CaO}, \mathrm{Fe}_{2} \mathrm{O}_{3}, \mathrm{Na} 2 \mathrm{O}$, a combination of these phases, and other ash constituents depending on the coal feedstock. X-ray diffraction data for the deposits, obtained in a CERF run with combustion of Pittsburgh coal, showed the dominant phases to be mullite $\left(3 \mathrm{Al}_{2} \mathrm{O}_{3} \cdot 2 \mathrm{SiO}_{2}\right)$, ordered calcian albite $\left[(\mathrm{Na}, \mathrm{Ca}) \mathrm{Al}(\mathrm{Si}, \mathrm{Al})_{3} \mathrm{O}_{8}\right]$, and hematite $\left(\mathrm{Fe}_{2} \mathrm{O}_{3}\right)$. The melting temperatures of these phases are $>1400^{\circ} \mathrm{C}$ (see Table 4 for a listing of melting temperatures of various 
compounds); reactions between these compounds and the ceramic materials occur primarily in the solid state, and little or no penetration of the ceramics occurs by liquid phase from coal combustion environment.

Similarly, X-ray diffraction data for the deposits, obtained in a CERF run with combustion of Alaskan/Russian blend coal, showed the dominant phases to be anorthite $\left(\mathrm{CaO} \cdot \mathrm{Al}_{2} \mathrm{O}_{3} \cdot 2 \mathrm{SiO}_{2}\right)$, calcium aluminum silicate $\left(\mathrm{CaO} \cdot \mathrm{Al}_{2} \mathrm{O}_{3} \cdot \mathrm{SiO}_{2}\right)$, and ordered sodium anorthite $(\mathrm{Ca}, \mathrm{Na})(\mathrm{Al}, \mathrm{Si})_{2} \mathrm{Si} 2 \mathrm{O}_{8}$. These $\mathrm{Ca}$ rich silicates also have melting temperatures $>1400^{\circ} \mathrm{C}$ (see Table 4), and reactions between the coal ash deposit and the ceramics occur predominantly in the solid state. The experimental results also indicate that $\mathrm{Na}_{2} \mathrm{O}$ activities in the deposits (with combustion of coals containing $\mathrm{Fe}_{2} \mathrm{O}_{3}$ and $\mathrm{CaO}$ ) are sufficiently low to form liquid sodium silicates of various types in coal-fired systems. At present, longterm experiments are in progress in the laboratory and in CERF to evaluate the corrosion performance of several ceramic and advanced metallic materials and to assess their residual mechanical properties.

\section{SUMMARY}

Thermodynamic calculations were performed to evaluate the chemistries of gaseous and condensed phases that arise during combustion of an Illinois bituminous coal. Coal combustion results in a liquid phase that is essentially a silica-saturated silicate-sulfate condensate, with the components being largely $\mathrm{CaO} \cdot \mathrm{SiO}_{2}, \mathrm{Na}_{2} \mathrm{O} \cdot 2 \mathrm{SiO}_{2}, \mathrm{FeO} \cdot \mathrm{SiO}, \mathrm{MgO} \cdot \mathrm{SiO}_{2}, \mathrm{Na}_{2} \mathrm{SO}_{4}$, and $\mathrm{NaCl}$. At temperatures below $1180^{\circ} \mathrm{C}$, the partial pressures of $\mathrm{NaCl}(\mathrm{g}), \mathrm{HCl}(\mathrm{g}), \mathrm{NaOH}(\mathrm{g})$, and $\mathrm{Na}(\mathrm{g})$ change abruptly; a complex sodium aluminosilicate, $\mathrm{Na}_{2} \cdot \mathrm{Al}_{2} \mathrm{O}_{3} \cdot 6 \mathrm{SiO}_{2}(\mathrm{~s})$, tends to form; and the liquid silicate-sulfate condensate disappears. Formation of the complex silicate requires intimate contacts among several gaseous and condensed phases, the probability of which is expected to be low in real systems. Under nonequilibrium conditions, where such reactions are constrained, stability of the liquid sulfatesilicate condensate extends to temperatures as low as $890^{\circ} \mathrm{C}$. Calculations also indicate that the silicate phases such as mullite and calcium aluminum silicate will dominate the deposit composition and that alkali-sulfate-induced corrosion, prevalent in gas turbine systems that use coal-derived gases, may not be of concern for heat exchangers in HIPPS.

Several ceramic materials have been examined to evaluate their performance after exposure to dry air, salt environments that contained $\mathrm{Na}_{2} \mathrm{SO}_{4}$ or $75 \mathrm{wt} . \% \mathrm{Na}_{2} \mathrm{SO}_{4}-25 \mathrm{wt} \% \mathrm{NaCl}$ mixture, and three different coal slags that simulated slags obtained from combustion of coals from eastern and western U.S. The results showed that the materials exposed to an air environment undergo passive oxidation of $\mathrm{SiC}$ to $\mathrm{SiO}_{2}$. Exposure of these materials to salt environments can lead to catastrophic corrosion, especially if the condensed salt has high sodium activity by enabling formation of low-melting corrosion products. On the other hand, exposure of the materials to slags obtained from typical coal ash had very little effect on the corrosion performance of the materials, especially at $1200^{\circ} \mathrm{C}$, where the reactions do not involve formation of liquid corrosion products. Four-point bend tests conducted on several of the materials after exposure to dry air, salt, and slag environments indicated that sodium salts (both sulfates and chlorides) have the most degrading effect on the properties, while exposure to air and slag environments had minimal effect on properties at $1200^{\circ} \mathrm{C}$.

\section{ACKNOWLEDGMENTS}

This work was supported by the U.S. Department of Energy, Office of Fossil Energy, Advanced Research and Special Technologies Materials Program. The author thanks the ceramics manufacturers for supplying specimen materials. The assistance of M. Mathur and M. Freeman of the Pittsburgh Energy Technology Center in the conduct of exposures in CERF is gratefully acknowledged. D. L. Rink assisted in the corrosion and four-point bend tests and microstructural analysis of exposed specimens.

\section{REFERENCES}

1. L. A. Ruth, “Combustion 2000," PETC Review, Issue 4, p. 4, 1991.

2. J. Shenker, "Development of a High-Performance Coal-Fired Power Generating System with a Pyrolysis Gas and Char-Fired High Temperature Furnace," Proc. 9th Annual Coal Preparation, Utilization, and Environmental Control Contractors' Conf., Pittsburgh, PA, 349, 1993.

3. D. J. Seery, J. J. Sangiovanni, F. L. Robson, W. M. Proscia, J. E. Holowczak. M. Bak, J. D. Freihaut, 
M. Heap, D. W. Pershing, and P. J. Smith, "Combustion 2000: Burning Coal in the Twenty-First Century," ibid., p. 356.

4. K. Natesan, M. Yanez-Herrero, and C. Fornasieri, "Corrosion Performance of Materials for Advanced Combustion Systems," Argonne National Laboratory Report ANL/FE-93/1, 1993.

5. K. Natesan, M. Yanez-Herrero, and C. Fornasieri, "High Temperature Corrosion in Advanced Combustion Systems," CORROSION/94, Baltimore, MD, Feb. 28-March 4, 1994.

6. S. C. Singhal, "Thermodynamic Analysis of the High-Temperature Stability of Silicon Nitride and Silicon Carbide," Cermamurgia Intl., 2(3), 123-130, 1976.

7. K. Natesan, M. Freeman, and M. Mathur, "Corrosion Performance of Materials for Advanced Combustion Systems," Proc. 9th Annual Conf. on Fossil Energy Materials, Oak Ridge, TN, May 1618, 1995, ORNL/FMP-95/1, 71, 1995.

8. K. Natesan, M. Freeman, and M. Mathur, "Corrosion and Its Effect on Mechanical Properties of Materials for Advanced Combustion Systems," Proc. 10th Annual Conf. on Fossil Energy Materials, Knoxville, TN, May 14-16, 1996, ORNL/FMP-96/1, 63, 1996.

Table 1. Materials selected for corrosion tests

\begin{tabular}{ll}
\hline \multicolumn{1}{c}{ Material } & \multicolumn{1}{c}{ Manufacturer } \\
\hline Hexoloy SA & Carborundum \\
SiC (I) particulate in alumina & Lanxide/Du Pont \\
Siliconized SiC (NT230) & Norton/TRW \\
Silicon nitride (NT154) & Norton/TRW \\
SiC fibers in SiC matrix & Du Pont \\
SiC fibers in SiC matrix & ORNL \\
SiC in Si matrix & INEX, Inc. \\
\hline
\end{tabular}

Table 2. Compositions (wt.\%) of slags for laboratory study

\begin{tabular}{cccc}
\hline & Slag 43/ & Slag 47/ & Slag XX/ \\
Compound & Illinois $\# 6$ & Rochelle & Illinois \#6 \\
\hline $\mathrm{SiO}_{2}$ & 52.9 & 47.1 & 53.3 \\
$\mathrm{Al}_{2} \mathrm{O}_{3}$ & 16.6 & 18.8 & 18.6 \\
$\mathrm{Fe}_{2} \mathrm{O}_{3}$ & 12.9 & 5.2 & 17.6 \\
$\mathrm{CaO}$ & 13.0 & 19.6 & 7.2 \\
$\mathrm{MgO}$ & 1.3 & 5.8 & 1.0 \\
$\mathrm{Na}_{2} \mathrm{O}$ & 0.8 & 0.9 & 0 \\
$\mathrm{~K}_{2} \mathrm{O}$ & 1.6 & 0.3 & 1.7 \\
$\mathrm{SO}_{3}$ & 0.1 & 0.3 & 0 \\
\hline
\end{tabular}

Table 3. Compositions (wt.\%) of coal ash

\begin{tabular}{cccccc}
\hline & $\begin{array}{c}\text { Ash 43/ } \\
\text { Compound }\end{array}$ & $\begin{array}{c}\text { Ash 47/ } \\
\text { Illinois }\end{array}$ Rochelle & $\begin{array}{c}\text { Ash XX/ } \\
\text { Illinois \#6 }\end{array}$ & $\begin{array}{c}\text { Ash 1/ } \\
\text { Pittsburgh }\end{array}$ & $\begin{array}{c}\text { Ash 2/ } \\
\text { Alaskan }\end{array}$ \\
\hline $\mathrm{SiO}_{2}$ & 56.5 & 32.1 & 51.6 & 41.5 & 43.1 \\
$\mathrm{Al}_{2} \mathrm{O}_{3}$ & 20.8 & 18.0 & 19.2 & 21.5 & 17.0 \\
$\mathrm{Fe}_{2} \mathrm{O}_{3}$ & 9.6 & 4.9 & 17.4 & 17.9 & 8.7 \\
$\mathrm{CaO}$ & 3.0 & 23.1 & 3.2 & 8.5 & 20.6 \\
$\mathrm{MgO}$ & 1.1 & 9.9 & 1.0 & 0.8 & 2.6 \\
$\mathrm{Na}_{2} \mathrm{O}$ & 1.7 & 1.5 & 0.9 & 0.6 & 0.6 \\
$\mathrm{~K}_{2} \mathrm{O}$ & 2.5 & 0.3 & 2.4 & 1.3 & 1.2 \\
$\mathrm{SO}_{3}$ & 1.8 & 8.0 & 2.3 & 4.0 & 5.6 \\
\hline Ash Fluidity & & & & & \\
Temperature $\left({ }^{\circ} \mathrm{C}\right)$ & 1405 & NA & 1400 & 1388 & 1288 \\
\hline
\end{tabular}


Table 4. Melting temperatures of coal slag components

\begin{tabular}{cc}
\hline Compound & $\begin{array}{c}\text { Melting } \\
\text { Temperature }\left({ }^{\circ} \mathrm{C}\right)\end{array}$ \\
\hline $\mathrm{Al}_{2} \mathrm{O}_{3}$ & 2020 \\
$\mathrm{SiO}_{2}$ & $1610-1723$ \\
$\mathrm{Fe}_{2} \mathrm{O}_{3}$ & 1594 \\
$\mathrm{CaO}$ & 2614 \\
$\mathrm{Na} 2 \mathrm{O} \cdot \mathrm{SiO}_{2}$ & 1089 \\
$\mathrm{Na}_{2} \mathrm{O} \cdot 2 \mathrm{SiO}_{2}$ & 874 \\
$\mathrm{Na}_{2} \mathrm{O} \cdot 4 \mathrm{SiO}_{2}$ & 1112 \\
$2 \mathrm{Na}_{2} \mathrm{O} \cdot \mathrm{SiO}_{2}$ & 1018 \\
$3 \mathrm{Al}_{2} \mathrm{O}_{3} \cdot 2 \mathrm{SiO}_{2}$ & 1850 \\
$\mathrm{Na} 2 \mathrm{O} \cdot \mathrm{Al}_{2} \mathrm{O}_{3} \cdot 2 \mathrm{SiO}_{2}$ & 1526 \\
$\mathrm{Na} 2 \mathrm{O} \cdot \mathrm{Al}_{2} \mathrm{O}_{3} \cdot 4 \mathrm{SiO}_{2}$ & 1138 \\
$\mathrm{Na} 2 \mathrm{O} \cdot \mathrm{Al}_{2} \mathrm{O}_{3} \cdot 6 \mathrm{SiO}_{2}$ & 1118 \\
$\mathrm{Na} 2 \mathrm{O} \cdot \mathrm{Fe}_{2} \mathrm{O}_{3} \cdot 4 \mathrm{SiO}_{2}$ & 1310 \\
$\mathrm{CaO} \cdot \mathrm{SiO}_{2}$ & 1544 \\
$2 \mathrm{CaO}_{2} \cdot \mathrm{SiO}_{2}$ & 2130 \\
$\mathrm{CaO} \cdot \mathrm{Al}_{2} \mathrm{O}_{3} \cdot 2 \mathrm{SiO}_{2}$ & 1553 \\
$\mathrm{Na}_{2} \mathrm{SO}_{4}$ & 884 \\
\hline
\end{tabular}

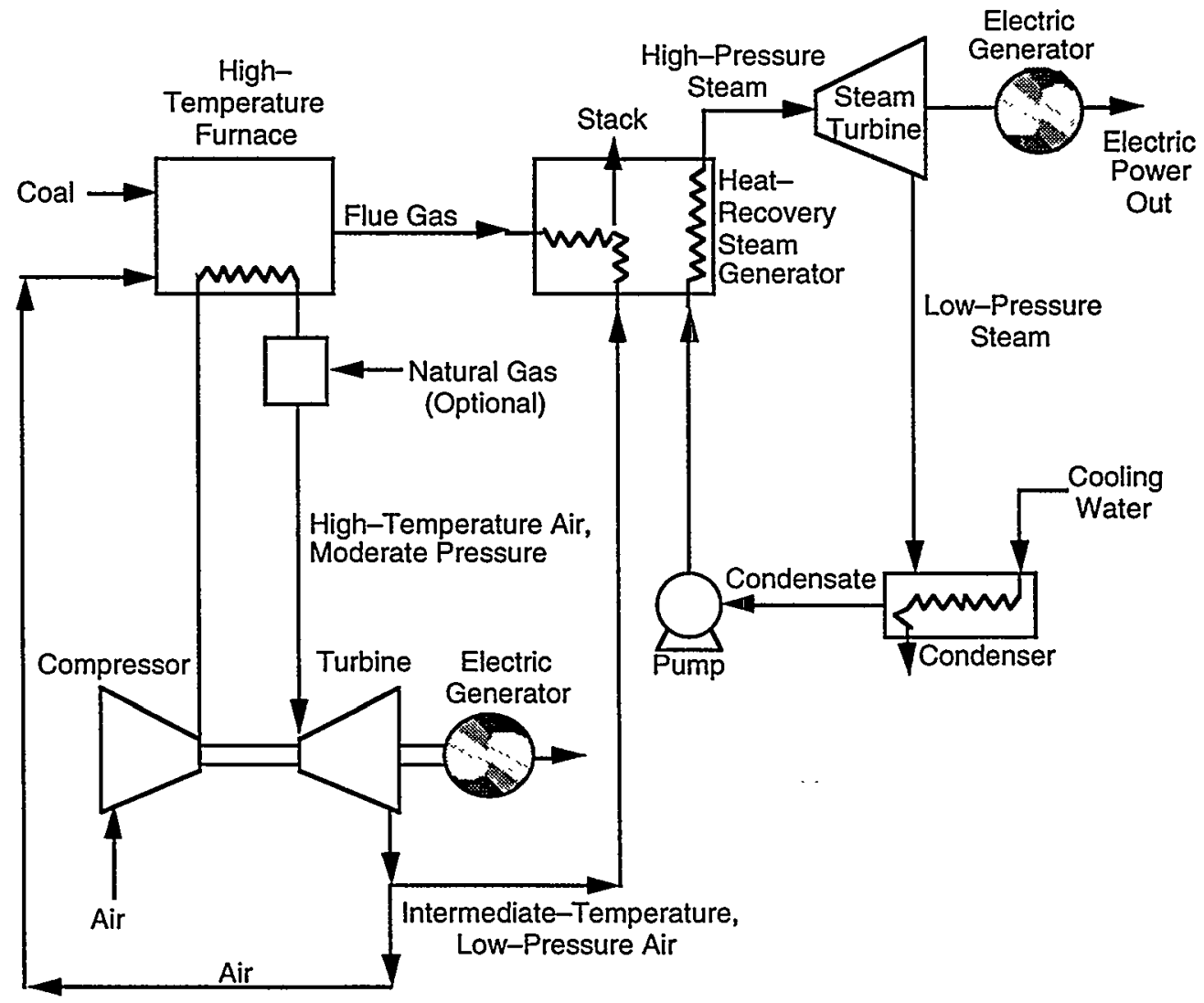

Figure 1. Schematic diagram of high performance power system. 


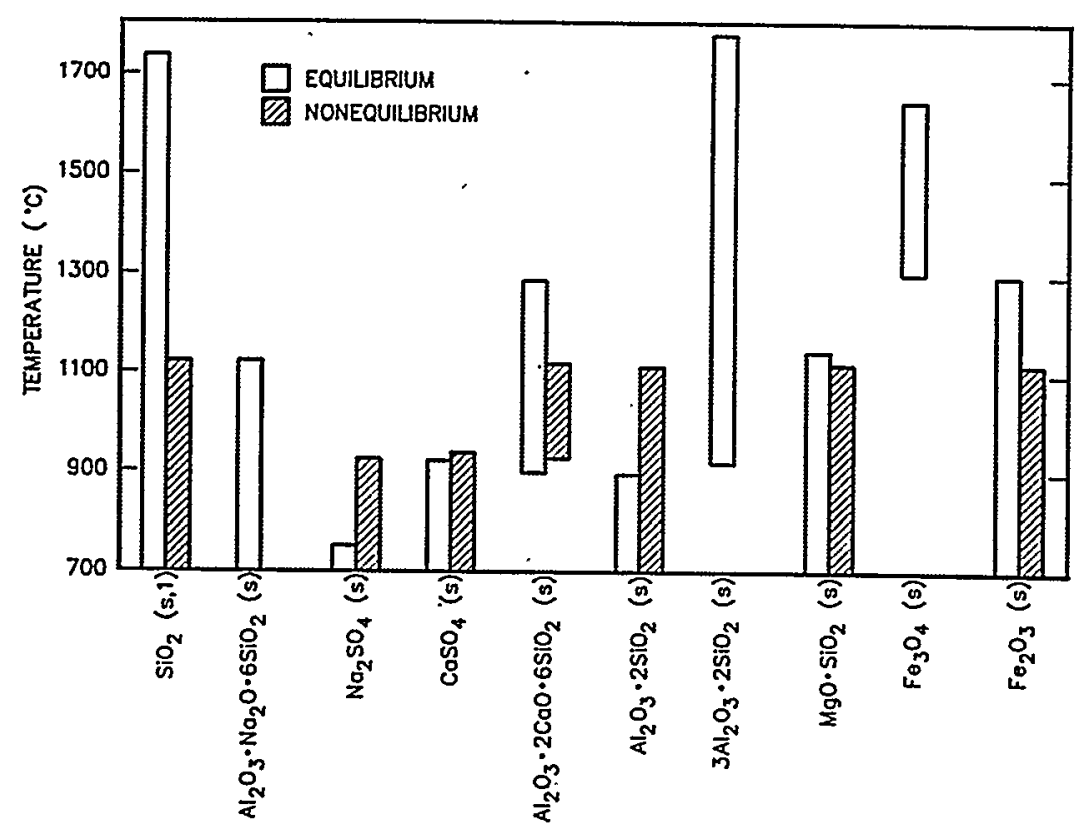

Fig. 2. Approximate temperature ranges for stability of condensed phases during combustion of highsulfur coal with $30 \%$ excess oxygen.

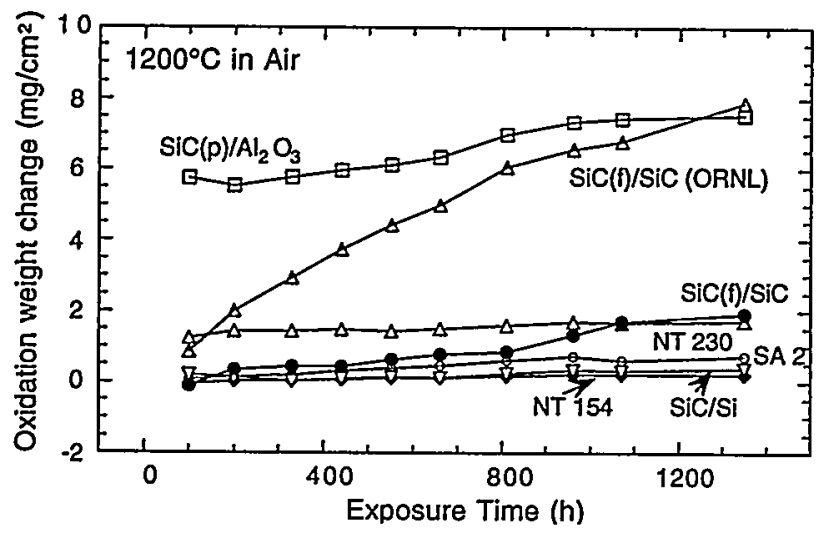

Fig. 3. Oxidation behavior of several ceramic materials in dry air at $1200^{\circ} \mathrm{C}$

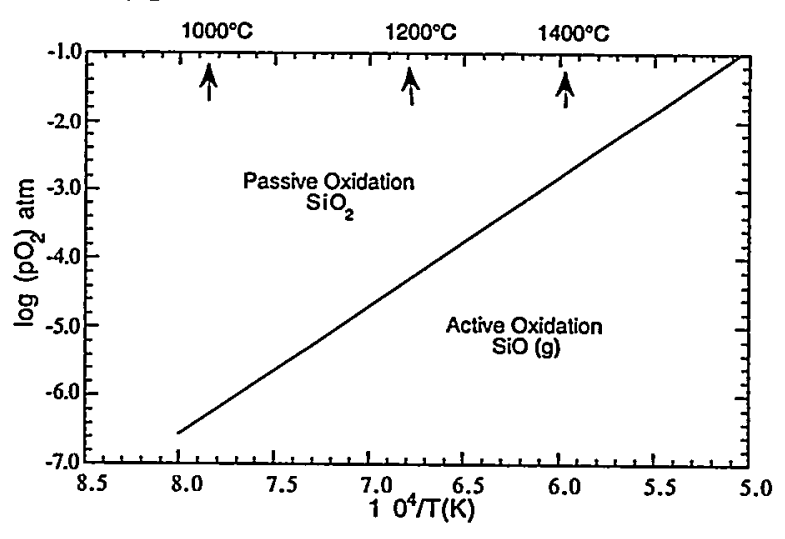

Fig. 4. Regions of active and passive oxidation of $\mathrm{SiC}$ in dry air.

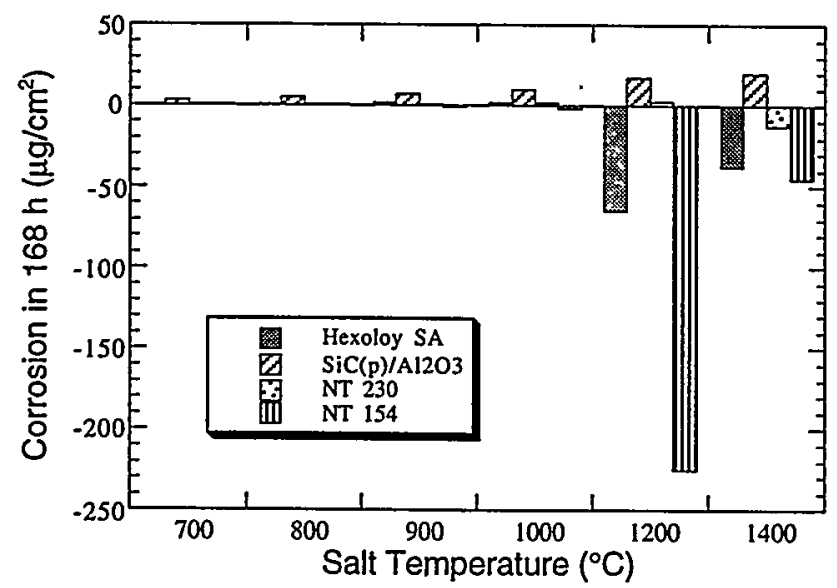

Fig. 5. Effect of sodium sulfate condensate on corrosion behavior of several ceramic materials at $1200^{\circ} \mathrm{C}$ 


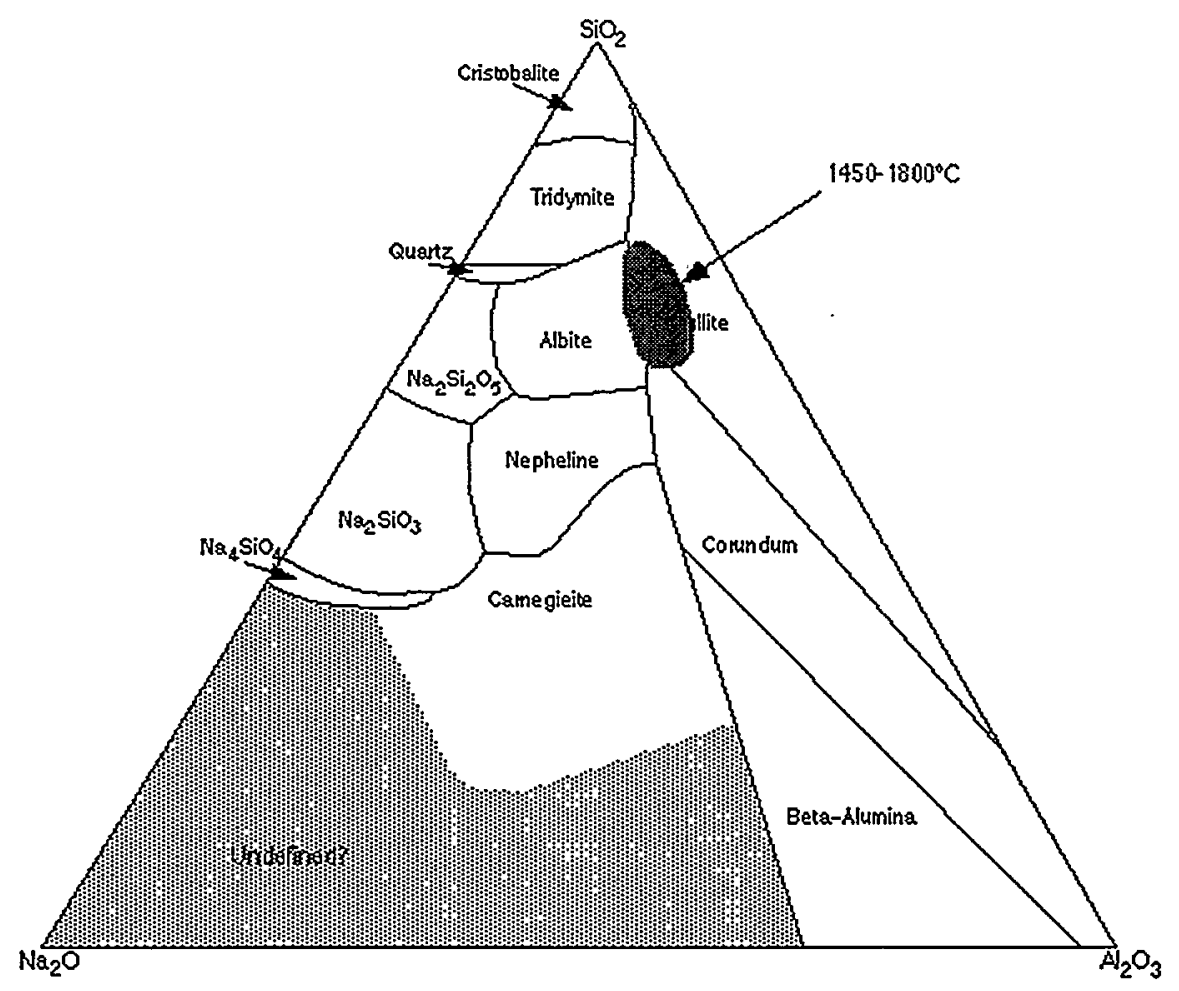

Fig. 6. Deposit composition envelope observed during combustion of Illinois \#6 coal (typical of eastern U.S. coal).

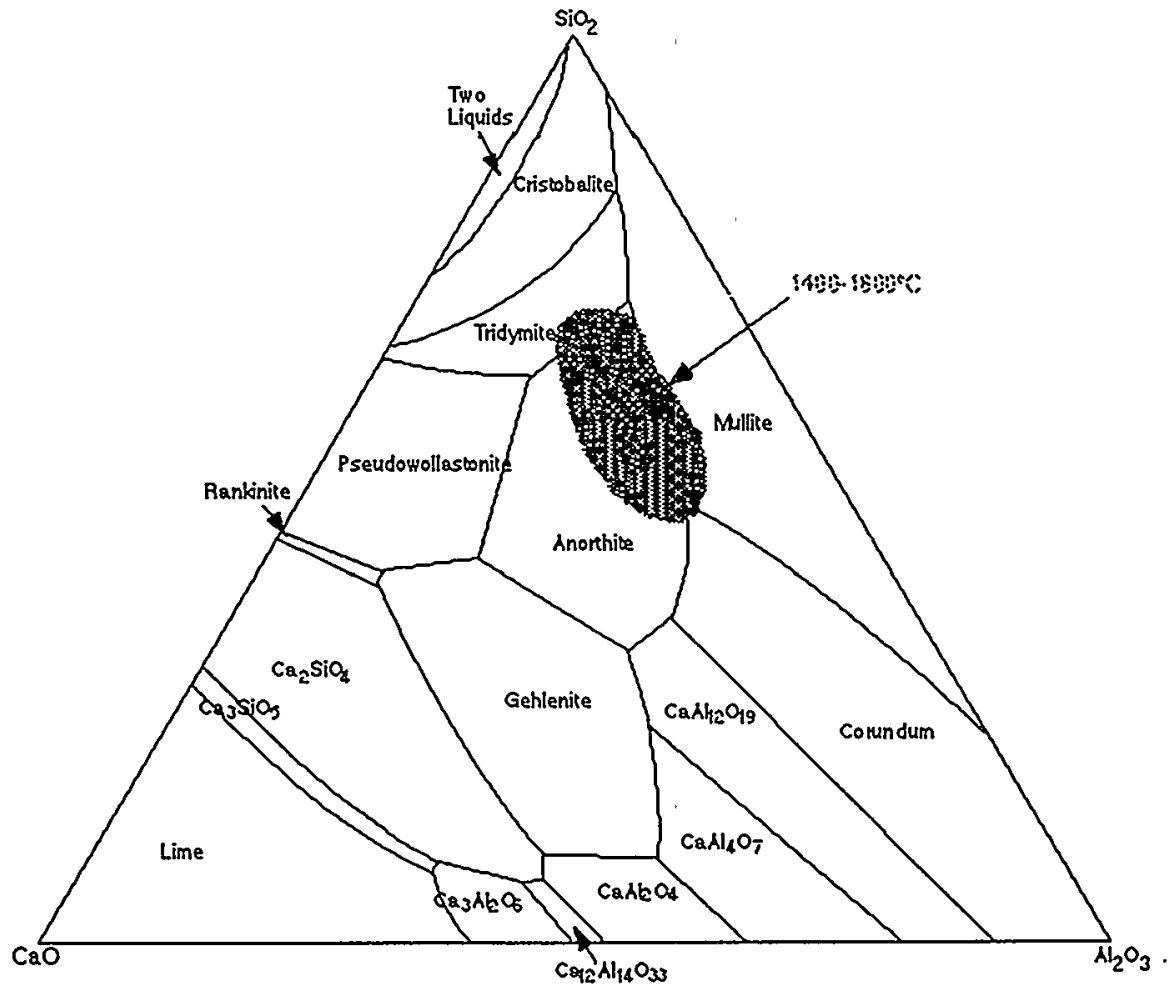

Fig. 7. Deposit composition envelope observed during combustion of Alaskan/Russian coal (typical of western U.S. coal). 

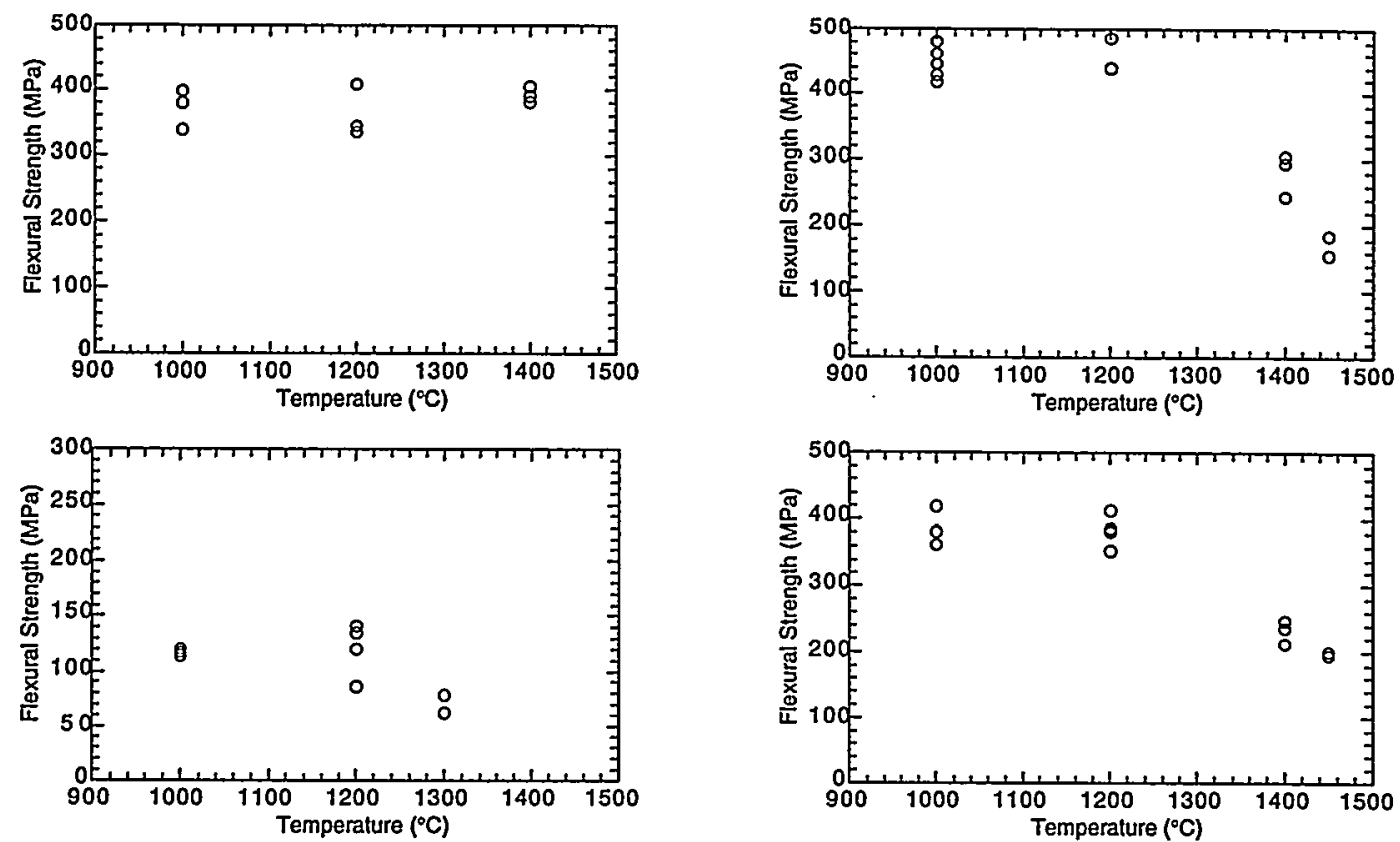

Fig. 8. Flexural Strength as function of temperature for Hexoloy SA (top left), NT 230 (top right), $\mathrm{SiC}$ in $\mathrm{Si}$ matrix (bottom left), and $\mathrm{SiC}(\mathrm{f})$ in $\mathrm{SiC}$ matrix (bottom right)
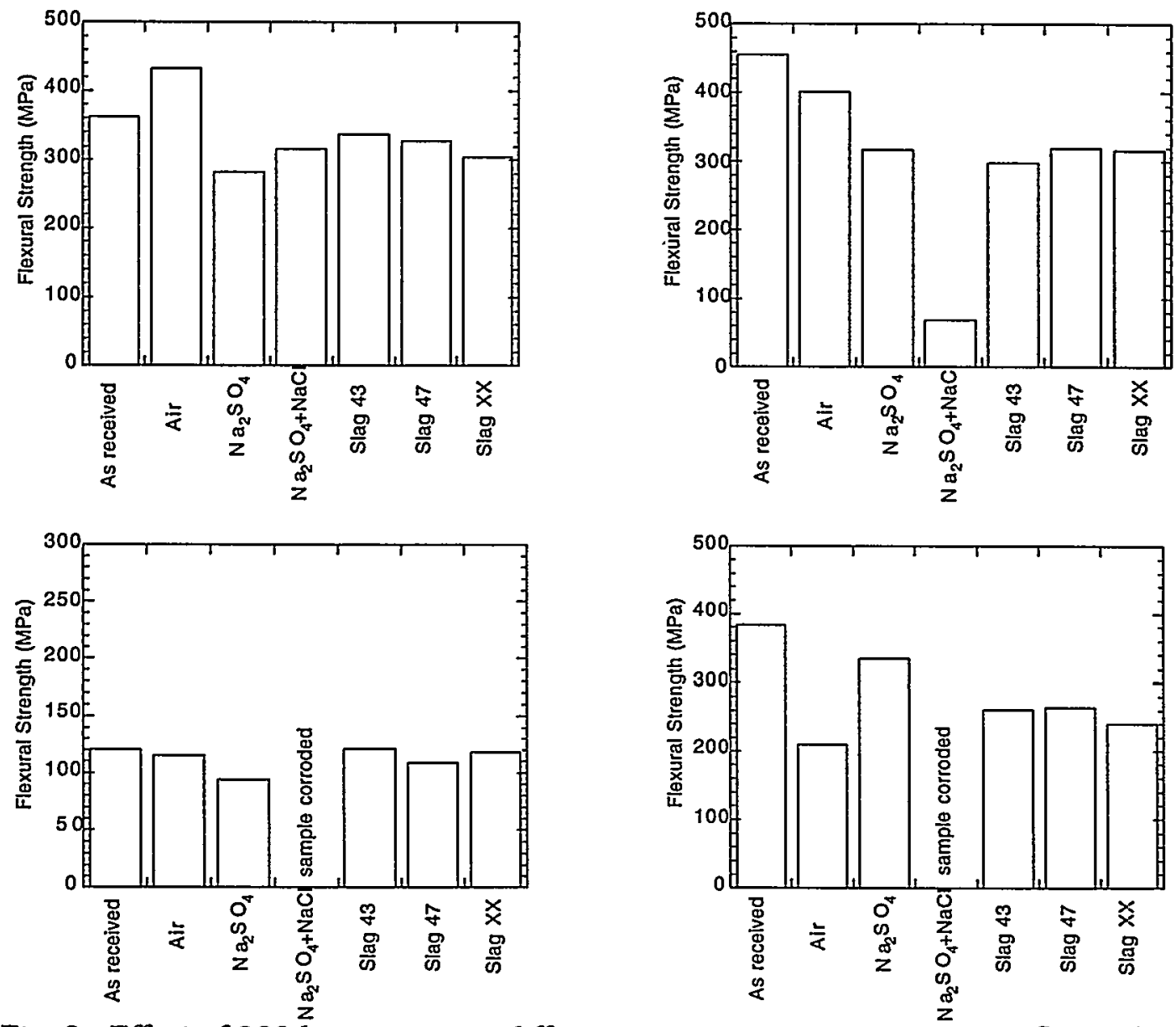

Fig. 9. Effect of $200 \mathrm{~h}$ exposure in different environments at $1200^{\circ} \mathrm{C}$ on flexural strength for Hexoloy SA (top left), NT 230 (top right), $\mathrm{SiC}$ in $\mathrm{Si}$ matrix (bottom left), and $\mathrm{SiC}(\mathrm{f})$ in $\mathrm{SiC}$ matrix (bottom right) 

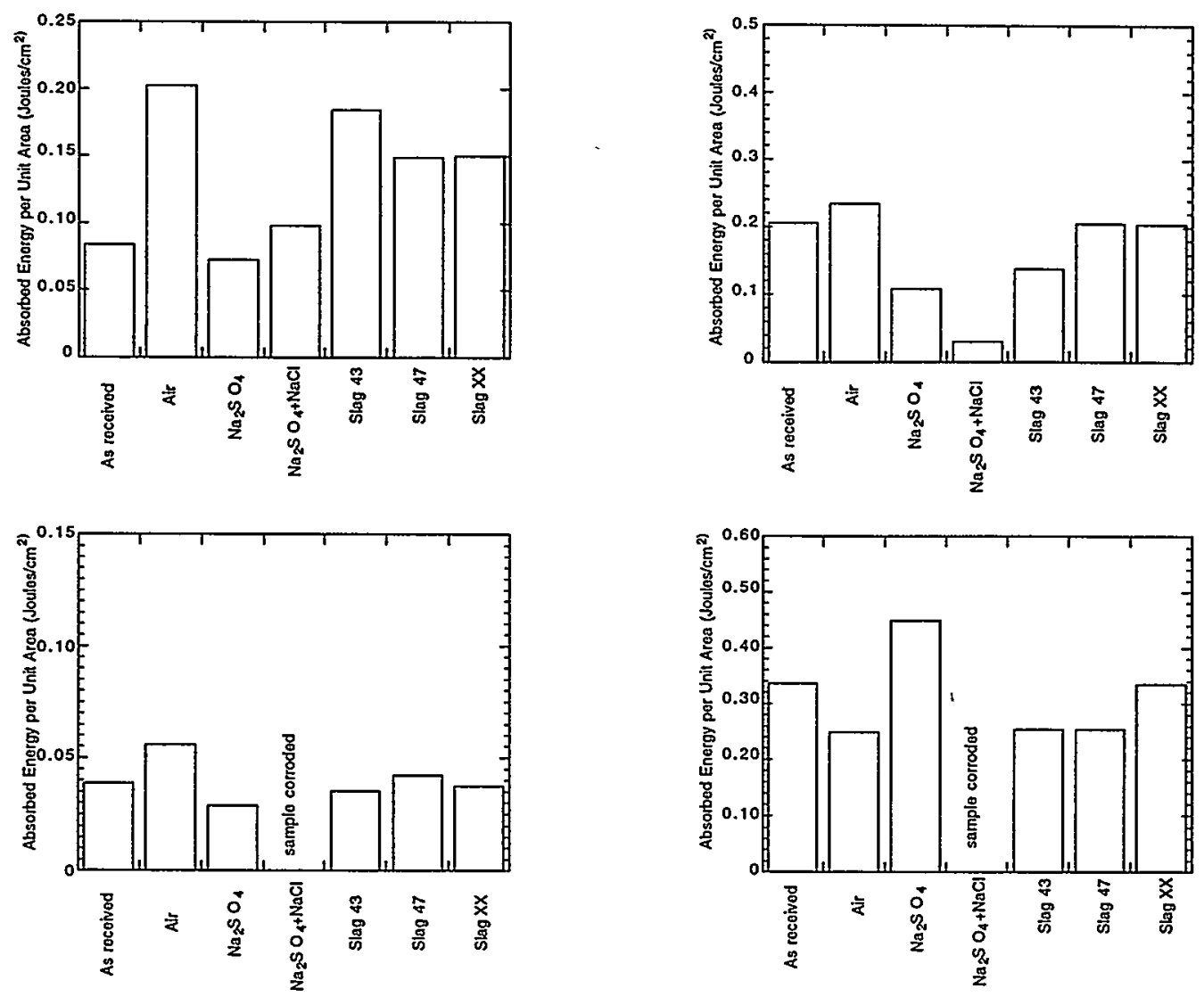

Fig. 10. Effect of $200 \mathrm{~h}$ exposure in different environments at $1200^{\circ} \mathrm{C}$ on absorbed energy per unit area for Hexoloy SA (top left), NT 230 (top right), SiC in $\mathrm{Si}$ matrix (bottom left), and $\mathrm{SiC}(\mathrm{f})$ in $\mathrm{SiC}$ matrix (bottom right) 